\title{
Nitrogen cycling through a fringing marsh-aquifer ecotone
}

\author{
Craig R. Tobias ${ }^{1, *}$, Iris C. Anderson ${ }^{1}$, Elizabeth A. Canuel ${ }^{1}$, Stephen A. Macko \\ ${ }^{1}$ School of Marine Science, Virginia Institute of Marine Science, College of William and Mary, Gloucester Point, \\ Virginia 23062, USA \\ ${ }^{2}$ Department of Environmental Science, University of Virginia, Charlottesville, Virginia 22901, USA
}

\begin{abstract}
Fringing wetlands are critical components of estuarine systems, and subject to water fluxes from both watersheds and estuaries. To assess the effect of groundwater discharge on marsh nitrogen cycling, we measured $\mathrm{N}$-cycling in sediments from a fringing mesohaline marsh in Virginia which receives a seasonal groundwater input. Mineralization, nitrification, potential denitrification (DNF), and potential dissimilatory nitrate reduction to ammonium (DNRA) rates were estimated along with porewater concentrations of oxygen, sulfide, and conductivity during high (May 1997) and low (October 1997) groundwater discharge. All N-cycling processes were confined to the upper 1 to $1.5 \mathrm{~m}$ of marsh, where organic matter and ammonium were most abundant. Depth-integrated rates for mineralization, nitrification, DNRA, and DNF ranged between 1.0-11.2, 0.0-2.2, 0.9-6.1, and 1.8-17.6 mmol $\mathrm{N} \mathrm{m}^{-2} \mathrm{~h}^{-1}$, respectively. During spring discharge (May), porewater conductivity, and dissolved sulfide decreased by approximately $50 \%$, and a groundwater-driven $\mathrm{O}_{2}$ flux of $27 \mu \mathrm{mol} \mathrm{m}{ }^{-2}$ $\mathrm{h}^{-1}$ into the marsh subsurface was estimated. Although mineralization, nitrification, and DNRA rates were up to $12 \times, 6 \times$, and $7.5 \times$ greater in May, respectively, than during low discharge (October), DNF was $10 \times$ higher in October. The largest difference in seasonal rates was observed nearest the upland border, where groundwater discharge had the greatest effect on sediment geochemistry. We suggest that a synergy between an increased flux of electron acceptors, porewater mixing, and flushing of salt and sulfide was responsible for the elevated mineralization and nitrification rates in May. Naturalabundance $\delta^{15} \mathrm{~N}$ measurements of the $\mathrm{NH}_{4}{ }^{+}, \mathrm{NO}_{3}{ }^{-}$, and $\mathrm{N}_{2}$ pools showed that nitrification is important in mediating $\mathrm{N}$ export by linking mineralization and denitrification in this marsh. However, despite accelerated mineralization and nitrification in May, there was not an equivalently large export of $\mathrm{N}$ via coupled nitrification-denitrification. The DNF:DNRA ratio in May (0.6) was 25-fold lower than that seen at low discharge, indicating that during spring discharge, a greater proportion of nitrified $\mathrm{N}$ was recycled internally rather than exported via denitrification.
\end{abstract}

KEY WORDS: Nitrogen $\cdot$ Marsh $\cdot$ Groundwater $\cdot$ Isotopes $\cdot$ Salinity

\section{INTRODUCTION}

Fringing marshes occur at the land-water interface and may be important sites of nitrogen cycling and transformation. The growth of marsh macrophytes can be directly or indirectly limited by nitrogen (Valiela \&

*Present address: Ecosystems Center, Marine Biological Laboratory, Woods Hole, Massachusetts 02543, USA.

E-mail: ctobias@mbl.edu
Teal 1974, Morris 1980, Dai \& Weigert 1996), and much of the study of $\mathrm{N}$ cycling in fresh- and saltwater marshes has been restricted to the rhizosphere where processes have direct relevance to macrophyte production or decomposition (DeLaune et al. 1983, Bowden 1986, Anderson et al. 1997). Similarly, methods used to determine the function of marshes (either as sources or sinks of materials) within the estuarine landscape have concentrated on processes in shallow sediments and fluxes between the sediment surface and 
tidal water or the atmosphere (Childers \& Day 1988, Childers 1994, Anderson et al. 1997).

The sediment surface represents an interface between a reducing sediment environment and an oxidizing water column or atmosphere, and is an active zone of nitrogen transformations. Of the multiple factors (Eh, pH, salinity, dissolved oxygen, dissolved inorganic nitrogen, and sulfide) controlling the pathways and magnitudes of different $\mathrm{N}$ transformations, labile organic carbon, oxygen, nitrate and sulfate supply have been considered the primary regulators of mineralization (MIN), nitrification (NIT), denitrification (DNF), and the dissimilatory reduction of nitrate to ammonium (DNRA). The oxygen $\left(\mathrm{O}_{2}\right)$ flux into sediment enhances nitrification, and controls the ratio of aerobic to anaerobic organic matter respiration (Howes et al. 1984, Thompson et al. 1995). Denitrification rates are amplified directly by the allochthonous input of $\mathrm{NO}_{3}{ }^{-}$, and indirectly by moderate $\mathrm{O}_{2}$ inputs through coupled nitrification/denitrification, but are inhibited by large atmospheric $\mathrm{O}_{2}$ fluxes to the marsh surface. Anaerobic $\mathrm{N}$ mineralization via sulfate reduction may inhibit both nitrification and denitrification if sulfide $\left(\mathrm{H}_{2} \mathrm{~S}\right)$ accumulates (Sorenson 1987, Joye \& Hollibaugh 1995). Further, high $\mathrm{H}_{2} \mathrm{~S}$ concentrations as well as low $\mathrm{NO}_{3}^{-}$:DOC ratios favor the retention of nitrogen in the system by proportionally increasing nitrate reduction to ammonium rather than denitrification to $\mathrm{N}_{2}$ (King \& Nedwell 1985, Tiedje 1988, Brunet \& Garcia-Gil 1996). With few exceptions, exchanges of these redox-active compounds with tidal water or the atmosphere across the sediment surface have been considered as the sole external forcings relevant to $\mathrm{N}$ cycling.

There exists, however, a second redoxcline between the marsh strata and the underlying aquifer which has been primarily overlooked. $\mathrm{N}$ cycling at this boundary may be important in processing allochthonous groundwater $\mathrm{N}$ loads prior to discharge to the adjacent water body, and altering internal marsh $\mathrm{N}$-cycling at high discharge. Because shallow coastal aquifers are typically oxic, and frequently contain $\mathrm{NO}_{3}{ }^{-}$as the dominant DIN species (Fetter 1993), discharging groundwater may represent a source of $\mathrm{N}$ and electron acceptors (e.g. $\mathrm{NO}_{3}{ }^{-}, \mathrm{O}_{2}$ ) to the marsh while concurrently flushing porewaters of accumulated salt and sulfide. Not all shallow aquifers, however, are enriched in nitrogen, and it is the potential flux of groundwater-derived electron acceptors $\left(\mathrm{O}_{2}\right)$, or the flushing effect of discharge that may have broader implications for nitrogen processing in affected marshes. Mineralization of organic $\mathrm{N}$ to ammonium can be accelerated in anaerobic sediments by the introduction of oxygen (Hansen \& Blackburn 1991), and nitrification is often oxygen-limited and tightly coupled to denitrification in ammonium-rich marsh sediments (Seitzinger 1994). Correla- tions between denitrification and oxygen-consumption rates in riparian wetlands suggest that the rate of $\mathrm{N}$ export from the system via coupled nitrification/denitrification may be accelerated by an influx of dissolved oxygen (Seitzinger 1994). Although the groundwater $\mathrm{O}_{2}$ concentrations are typically lower than those encountered in tidal water and in the atmosphere, the advective flux of groundwater in some marshes can be seasonally strong and dominate the sediment-water balance when discharge is high (Tobias 1999).

In this study we examined nitrogen cycling in a fringing mesohaline marsh that receives a seasonal input of fresh, low DIN, groundwater. We describe changes in subsurface geochemistry between periods of high and low groundwater discharge (May and October), and present rates of mineralization, nitrification, potential denitrification, and potential dissimilatory nitrate reduction to ammonium from the marsh surface into the underlying aquifer during those periods.

\section{METHODS}

Site description. The Ringfield Marsh study site is located in the Colonial National Historical Park (37 $\left.16^{\prime} 42^{\prime \prime} \mathrm{N}, 76^{\circ} 35^{\prime} 16^{\prime \prime} \mathrm{W}\right)$ bordering the York River in southeastern Virginia (Fig. 1). It consists of an upland slope of approximately 1:1, which grades through a mixed community of Spartina cynosuroides and S. alterniflora (short form) into a monotypic $S$. alterniflora (short form) fringing marsh approximately $25 \mathrm{~m}$ in width. The study area borders the mesohaline portion of the York River. The small-scale marsh consists of an upper 30 to $80 \mathrm{~cm}$ of sandy marsh peat underlain by a semi-continuous layer of lower-permeability, glauconitic, silty sand of 10 to $20 \mathrm{~cm}$ thickness. Below 150 to $200 \mathrm{~cm}$, the glauconitic deposits grade into cleaner oxidized, iron-rich sands and shell hash of pre-Holocene origin. The site receives maximal groundwater discharge (approximately $20 \mathrm{l} \mathrm{m}^{-2} \mathrm{~d}^{-1}$ ) between January and July, and receives little or no discharge from August through December (Tobias 1999). Shallow groundwater contains $<2 \mu \mathrm{M}$ dissolved inorganic $\mathrm{N}$.

Porewater characterization. Field sampling: Porewaters were collected from a multi-level piezometer transect extending from the upland marsh border to $15 \mathrm{~m}$ into the marsh (Fig. 1). The transect contained 5 piezometer clusters $(\mathrm{r}-1 \rightarrow \mathrm{r}-5)$, with each cluster composed of 4 to 5 piezometers spanning sediment depths from $5 \mathrm{~cm}$ to $2.5 \mathrm{~m}$ below the sediment surface at increments of $50 \mathrm{~cm}$. Piezometers were sealed to the atmosphere, and purged immediately prior to sampling.

Physical, chemical, and isotopic analyses: Temperature, $\mathrm{pH}$, conductivity, dissolved oxygen (DO), sulfide $\left(\mathrm{H}_{2} \mathrm{~S}\right)$, dissolved organic carbon (DOC), and nat- 


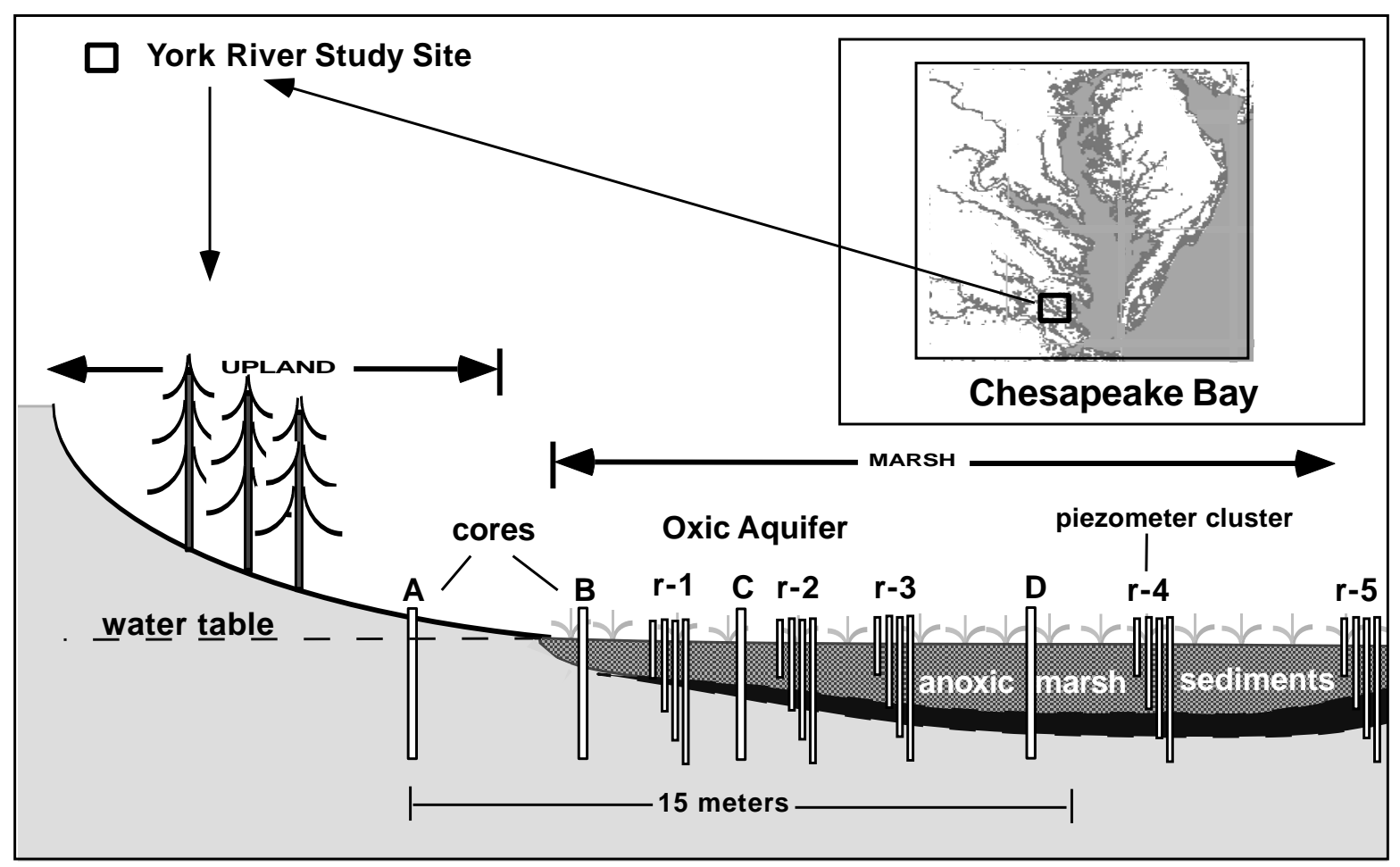

Fig. 1. Site location and cross section. Letters A to D denote location of cores taken in August 1996; 'border' and 'marsh' cores were taken at Positions B and C respectively. r-1 through r-5: positions of multi-level piezometers

ural abundance $\delta^{15} \mathrm{~N}-\mathrm{NH}_{4}{ }^{+}, \delta^{15} \mathrm{~N}-\mathrm{NO}_{3}{ }^{-}$ and dissolved $\delta^{15} \mathrm{~N}-\mathrm{N}_{2}$ were determined for porewaters collected from the site (Table 1). Isotopic determination of DIN and $\mathrm{N}_{2}$ was performed on porewater from Piezometer Nest r-2. All other chemical analyses were performed on porewater from all piezometers. Temperature and $\mathrm{pH}$ were determined in the field. Dissolved oxygen (DO) was determined using the azide modification of the Winkler titration method (Benson \& Krause 1984). Samples for sulfide $\left(\mathrm{H}_{2} \mathrm{~S}\right)$ analysis were collected, filtered immediately, and preserved with $6 \%$ zinc acetate according to Hines et al. (1989), and quantified spectrophotometrically according to Cline (1969). Dissolved organic carbon (DOC) was determined on porewaters filtered through combusted $0.7 \mu \mathrm{m}$ glass-fiber filters and analyzed with a Shimadzu TOC 5000 total organic carbon analyzer. $\delta^{15} \mathrm{~N}$ isotopic analysis of $\mathrm{NH}_{4}{ }^{+}, \mathrm{NO}_{3}{ }^{-}$, and $\mathrm{N}_{2}$ was performed on porewater samples collected in December 1996 and March 1997. Water samples for
Table 1. Summary of analyses of sediments and porewaters $(x=$ parameters measured). Sediments were characterized to a depth of $2 \mathrm{~m}$ at 10 to $20 \mathrm{~cm}$ intervals. Porewaters were characterized to a depth of $2 \mathrm{~m}$ in $50 \mathrm{~cm}$ intervals. DO: dissolved oxygen

\begin{tabular}{|lccccc|}
\hline & Aug 96 & Sep 96 & Dec 96 & May 97 & Oct 97 \\
\hline Groundwater flow & Low & Low & Low-moderate & High & Low \\
Sediment & & & & & \\
Eh & $\times$ & & & & \\
DIN & $\times$ & $\times$ & & $\times$ & $\times$ \\
C:N & $\times$ & & & & \\
$\delta^{15}$ N-PON & $\times$ & & & & \\
Mineralization & & & & $\times$ & $\times$ \\
Nitrification & & & $\times$ & $\times$ \\
Denitrification potential & & & $\times$ & $\times$ \\
DNRA potential & & & & $\times$ & $\times$ \\
Porewater & & & & $\times$ & $\times$ \\
Conductivity & & & & $\times$ & $\times$ \\
Temperature & & & & $\times$ & $\times$ \\
pH & & & $\times$ & $\times$ \\
DO & & & $\times$ & $\times$ \\
DOC & & & $\times$ & $\times$ \\
$\mathrm{H}_{2} \mathrm{~S}$ & & & & \\
$\delta^{15} \mathrm{~N}-\mathrm{DIN}$ & & $\times$ & & \\
$\delta^{15} \mathrm{~N}-\mathrm{N}_{2}$ & & & $\times$ & & \\
\hline
\end{tabular}

$\delta^{15} \mathrm{NH}_{4}^{+}$and $\delta^{15} \mathrm{NO}_{3}^{-}$analyses were filtered through $0.7 \mu \mathrm{m}$ ashed glass-fiber filters and frozen. Isolation of $\mathrm{NH}_{4}{ }^{+}$and $\mathrm{NO}_{3}{ }^{-}$for natural abundance $\delta^{15} \mathrm{~N}$ character- 
ization was performed sequentially on the same sample fraction according to the steam distillation-zeolite binding technique described by Velinsky et al. (1989). $\delta^{15} \mathrm{~N}$-DIN was determined using an isotope ratio-mass spectrometer (IRMS) at the University of Virginia (UVA). Samples for dissolved $\delta^{15} \mathrm{~N}_{2}$ determination were pumped from piezometers with a peristaltic pump, stored in $13 \mathrm{ml}$ Hungate tubes without headspace, and preserved with $\mathrm{ZnCl}_{2}(10 \% \mathrm{w} / \mathrm{v})$. Tubes were stored at $5^{\circ} \mathrm{C}$ under water until $3 \mathrm{~d}$ prior to isotopic analysis, when a $4 \mathrm{ml}$ ultra-high-purity helium headspace was introduced into the tubes. Tubes were vortexed for $5 \mathrm{~min}$ to promote headspace equilibration and returned to storage. For isotope analysis, $1.5 \mathrm{ml}$ of headspace was withdrawn with a gas-tight syringe and injected into a vacuum line, $\mathrm{CO}_{2}$ was cryogenically removed, and the $\delta^{15} \mathrm{~N}_{2}$ was determined by IRMS (UVA).

Sediment characterization and determination of $\mathbf{N}$ cycling rates. Field sampling: Core tubes were constructed from a $3 \mathrm{~m}$ length of $5.08 \mathrm{~cm}$-diam. PVC pipe perforated with $1 \mathrm{~mm}$-diam. holes drilled at $1 \mathrm{~cm}$ intervals along the length of the tube. All holes (injection ports) were sealed with silicone prior to sampling. Cores were driven to a depth of 2 to $3 \mathrm{~m}$ below the marsh surface using a jack hammer.

Physical chemical and isotopic analyses: A summary of sediment sampling is shown in Table 1. Four $2 \mathrm{~m}$ cores (Locations A to D: Fig. 1) were collected in August 1996. Four $1 \mathrm{~m}$ cores (Locations B to D) were collected in September 1996. Nine 2 m cores (Locations $\mathrm{B}, \mathrm{C}$, and midway between $\mathrm{B}$ and $\mathrm{C}$ ) were collected in May and October 1997. Wet bulk density, \% water, porosity, and \% organic matter were determined on 10 to $20 \mathrm{~cm}$ core subsections according to standard methods (Reay et al. 1995). Downcore Eh profiles were determined using a $\mathrm{pH}$ meter equipped with a finegauge platinum Eh electrode and a calomel reference electrode (Patrick et al. 1996). C:N ratios and $\delta^{15} \mathrm{~N}$ PON were determined simultaneously on dried, acidified, homogenized sediment-core subsections using an Optima IRMS/Elemental Analyzer (UVA). Exchangeable DIN had previously been removed from the wet sediment using a $2 \mathrm{~N} \mathrm{KCl}$ extraction technique modified from Bremner \& Keeney (1966) with a sediment: $\mathrm{KCl}$ ratio of $1: 2 . \mathrm{NH}_{4}{ }^{+}$and $\mathrm{NO}_{3}{ }^{-}$in the extract were quantified in the August and September 1996 cores, and as part of the determination of $\mathrm{N}$ cycling rates in cores collected in May and October 1997. The extract was $0.2 \mu \mathrm{m}$-filtered and frozen until analysis. Ammonium was determined by the phenol hypochlorite method of Solórzano (1969). Nitrate was determined spectrophotometrically using an Alpkem autoanalyzer by cadmium reduction to nitrite and diazotization (Perstorp 1992).
N cycling rates: Measurements of gross nitrification, gross mineralization, and potential DNRA were performed on cores collected in May and October 1997 at sites located 2 and $6 \mathrm{~m}$ (Fig. 1B,C respectively) into the marsh from the upland border. Denitrification potential was assessed in slurried sediments from cores collected during the same period. Cores for DNF experiments were collected midway between the border $(2 \mathrm{~m})$ and marsh $(6 \mathrm{~m})$ core sampling locations. Mineralization rates were determined following the ${ }^{15} \mathrm{NH}_{4}{ }^{+}$isotope dilution technique outlined by Davidson et al. (1990). For each experiment (May and October 1997), argon-sparged ${ }^{15}\left(\mathrm{NH}_{4}\right)_{2} \mathrm{SO}_{4}$ was injected into each siliconed injection port along the length of the core to achieve a final porewater concentration of $300 \mu \mathrm{M}$ and 30 at. $\%{ }^{15} \mathrm{~N}$ enrichment. Cores $(\mathrm{n}=4)$ were incubated intact in the horizontal position at $23^{\circ} \mathrm{C}$, and sacrificed at time, $t=0$ and $24 \mathrm{~h}$ for the May experiment, and at $t=0$ and $72 \mathrm{~h}$ for the October experiment. Cores were sectioned into 10 or $20 \mathrm{~cm} \mathrm{sec-}$ tions, extruded from the core tube, and the ammonium extracted with $\mathrm{KCl}$, filtered, frozen, and analyzed for $\left[\mathrm{NH}_{4}{ }^{+}\right]$and ${ }^{15} \mathrm{~N}-\mathrm{NH}_{4}{ }^{+}$. Isolation of the $\mathrm{NH}_{4}{ }^{+}$for ${ }^{15} \mathrm{~N}$ isotopic analysis followed the diffusion procedure described by Brooks et al. (1989). Isotope analyses were performed at the University of California Davis, Stable Isotope Facility. Due to the potential uptake and rerelease of labelled $\mathrm{NH}_{4}{ }^{+}$, the isotope-dilution technique provided a conservative estimate of gross mineralization (Thybo-Christesen 1993).

Nitrification rates were determined by ${ }^{15} \mathrm{NO}_{3}{ }^{-}$isotope dilution. Intact cores were injected with an argonsparged solution of $\mathrm{K}^{15} \mathrm{NO}_{3}$ to achieve a final porewater concentration of $300 \mathrm{\mu M} \mathrm{NO}_{3}{ }^{-}$and 30 at. $\%{ }^{15} \mathrm{~N}$ enrichment. Cores ( $\mathrm{n}=4$ per experiment) were incubated horizontally and sacrificed at $t=0$ and $t=16 \mathrm{~h}$ (top $40 \mathrm{~cm}$ ), or $t=67 \mathrm{~h}$ (lower $160 \mathrm{~cm}$ ) for the May experiment, and $t=0$ and $12 \mathrm{~h}$ (top $40 \mathrm{~cm}$ ), or 66 hours (lower $160 \mathrm{~cm}$ ) for the October experiment. Incubation of the top $40 \mathrm{~cm}$ was limited to 16 and $12 \mathrm{~h}$ because of high nitrate reduction rates encountered in those strata. $\mathrm{NO}_{3}{ }^{-}$was extracted with $\mathrm{KCl}$ and isolated for isotopic analysis as described by Brooks et al. (1989). Mineralization and nitrification rates were calculated using the model of Wessel \& Tietema (1992), which assumes that rates are constant during the duration of the incubation. Given the relatively long incubation times, and the potential for oxidant depletion during the incubation, this model may yield conservative gross-rate estimates.

Potential DNRA rates were estimated from the ${ }^{15} \mathrm{NO}_{3}{ }^{-}$-enriched incubations. A specific rate of ${ }^{15} \mathrm{~N}$ uptake into the ammonium pool was determined from the $\mathrm{NH}_{4}{ }^{+}$and $\mathrm{NO}_{3}{ }^{-}$isotope data, and used to calculate the potential DNRA rate according to isotope tracer equations presented in Glibert \& Capone (1993). 
Denitrification potential was determined in slurries using the acetylene block technique (Knowles 1990). Cores collected in May and October 1997 were sectioned into 10 or $20 \mathrm{~cm}$ intervals, split into thirds, and each third mixed with porewater collected from a similar depth in a ratio of 1:3 by volume. Slurries were sparged with argon, and an acetylene-sparged $\mathrm{KNO}_{3}$ solution was injected into the slurry to achieve a final concentration of $300 \mu \mathrm{M}$ $\mathrm{NO}_{3}{ }^{-}$. Acetylene gas was injected into the headspace of the incubation flasks to achieve a final dissolved $\mathrm{C}_{2} \mathrm{H}_{2}$ concentration of 10 to $15 \%$. Headspace samples were withdrawn with a gas-tight syringe $(t=0,5$, and $22 \mathrm{~h}$ in May, and $t=0$ and $24 \mathrm{~h}$ in October) and analyzed for $\mathrm{N}_{2} \mathrm{O}$ using gas chromatography (electron-capture detector/Poropak Q column). Total dissolved $\mathrm{N}_{2} \mathrm{O}$ concentrations were calculated from headspace values using the Ostwald coefficient (Weiss \& Price 1980). The potential denitrification rates were estimated from the slope of the linear regression of the $\mathrm{N}_{2} \mathrm{O}$ versus time plots for the May experiment, and by dividing total $\mathrm{N}_{2} \mathrm{O}$ production by the incubation time for the October experiment $\left(t_{0}\right.$ and $t_{\text {final }}$ measurements only).

\section{RESULTS}

\section{Porewater analysis}

The May high groundwater-discharge period was coincident with lower porewater conductivity and increased subsurface DO concentrations (Fig. 2). The horizontal and vertical extent of freshwater intrusion decreased between May and October, when salt encroachment into the shallow upland aquifer was observed. During both low and high groundwater flow, the conductivity in the subsurface was lower than that of tidal water infiltrating the site by 30 and $70 \%$, respectively.

Concurrent with high discharge in May, there was an increase in DO concentration and penetration into shallow marsh sediments (Fig. 2). DO concentrations increased with increasing sediment depth and distance into the upland to maximal values of 65 and $40 \mu \mathrm{M}$ for May and October, respectively. Nearly all of the marsh subsurface to a depth of $2.25 \mathrm{~m}$ was anoxic $(\mathrm{DO}<5 \mu \mathrm{M})$ in October, while DO concentrations above $10 \mu \mathrm{M}$ at depths $>1 \mathrm{~m}$ in May were encountered to a distance of
High Groundwater Discharge (May 1997)
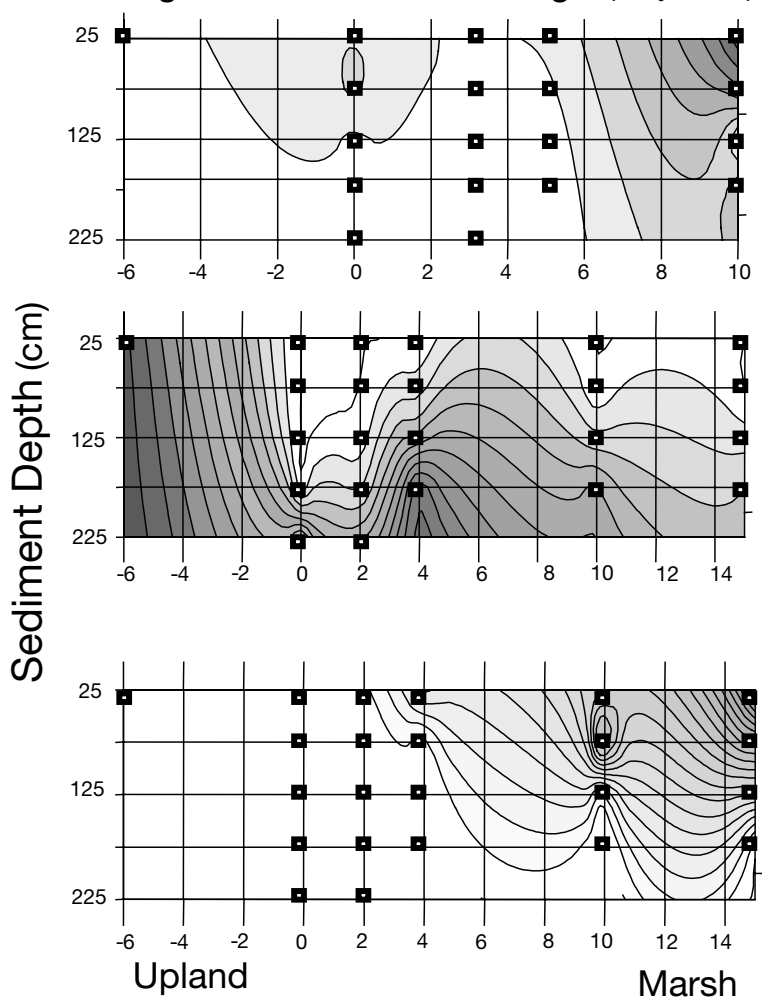

Low Groundwater Discharge (Oct 1997)
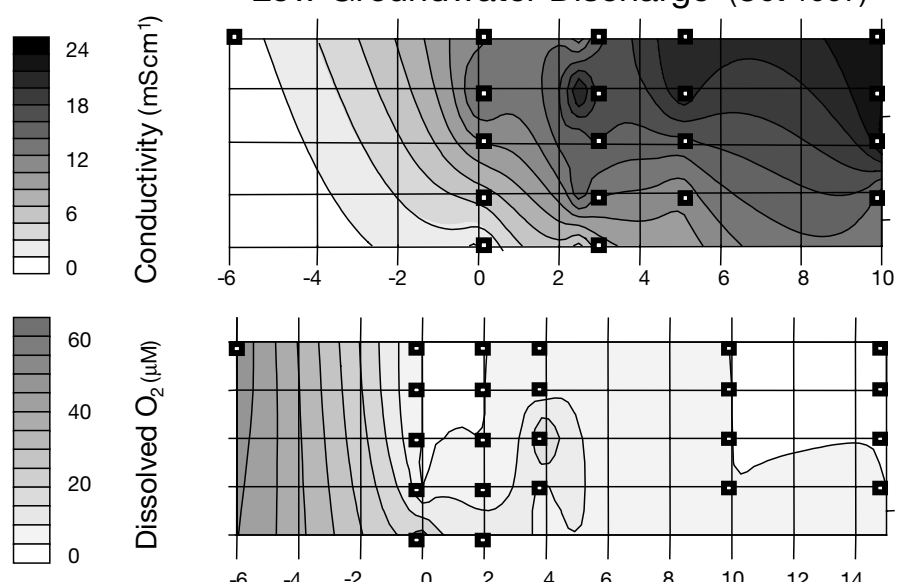

\section{位}
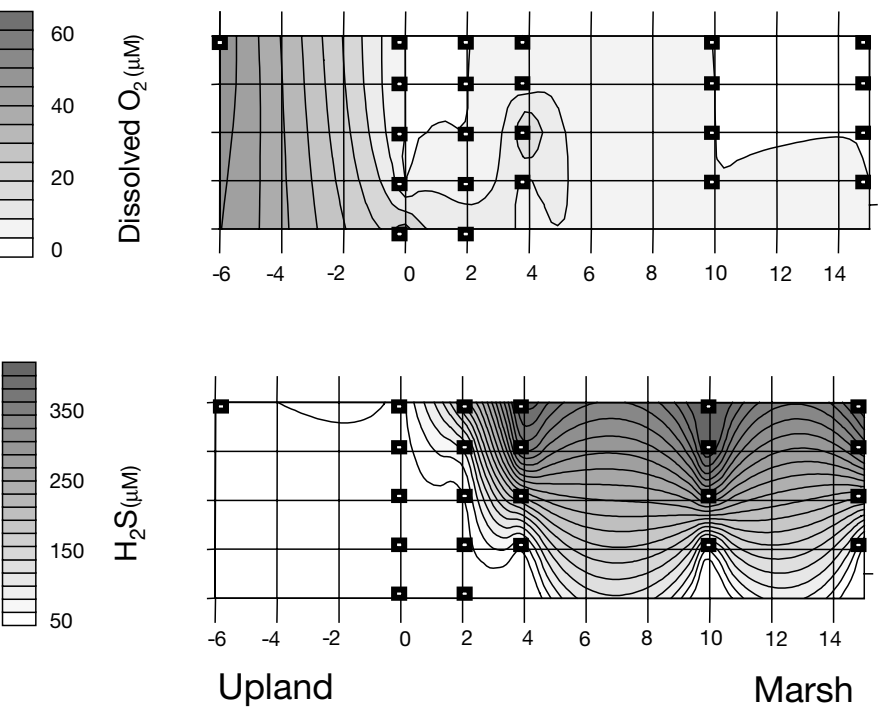

Shore Normal Distance $(\mathrm{m})$

Fig. 2. Summary of subsurface conductivity, dissolved oxygen, and sulfide concentrations during periods of high and low groundwater discharge. Squares indicate sampling locations. Border between the marsh and the upland is located at the shorenormal distance $=0$ 
$15 \mathrm{~m}$ from the upland border. Multiplying the maximal upland groundwater DO concentrations by estimates of groundwater discharge in May and October of 10.0, and $0.01 \mathrm{~m}^{-2} \mathrm{~d}^{-1}$ respectively (Tobias 1999 ) yielded a total groundwater-derived flux of DO to the upper $1 \mathrm{~m}$ of marsh in May of $650 \mu \mathrm{M} \mathrm{m}^{-2} \mathrm{~d}^{-1}$.

Average $\mathrm{H}_{2} \mathrm{~S}$ concentrations in the upper $2 \mathrm{~m}$ of marsh (Fig. 2) were approximately 2 to 4 times higher during October than in May. Generally, $\mathrm{H}_{2} \mathrm{~S}$ concentrations decreased with increasing sediment depth and increased with distance into the marsh. Maximal $\mathrm{H}_{2} \mathrm{~S}$ concentrations of nearly 250 and $500 \mu \mathrm{M}$ were detected in the upper $25 \mathrm{~cm}$ of sediment and $15 \mathrm{~m}$ into the marsh from the upland during May and October, respectively. In May, the zone of marsh within $5 \mathrm{~m}$ of the upland border was nearly sulfide-free, while during October $\mathrm{H}_{2} \mathrm{~S}$ encroached landward in shallow sediments to within $1 \mathrm{~m}$ of the upland border (Fig. 2).

Maximal DOC concentrations of 1400 and $400 \mu \mathrm{M}$ were found during October and May, respectively (Fig. 3). The highest concentrations were encountered in the shallow rhizosphere during both sample periods, and decreased exponentially to $50 \mu \mathrm{M}$ at approximately $2 \mathrm{~m}$ depth during both seasons. DOC was elevated in October relative to May at all depths and by a factor of 3.5 in the upper $50 \mathrm{~cm}$. The DOC concentration in the upland aquifer was between 50 and $168 \mu \mathrm{M}$ throughout the year.

$\delta^{15} \mathrm{~N}-\mathrm{PON}$ increased with increasing sediment depth (from 3 to $10 \%$ ) from the surface to $2 \mathrm{~m}$ (Fig. 4). With the exception of the $80 \mathrm{~cm}$ depth, all $\delta^{15} \mathrm{~N}^{-\mathrm{NH}_{4}{ }^{+}}$

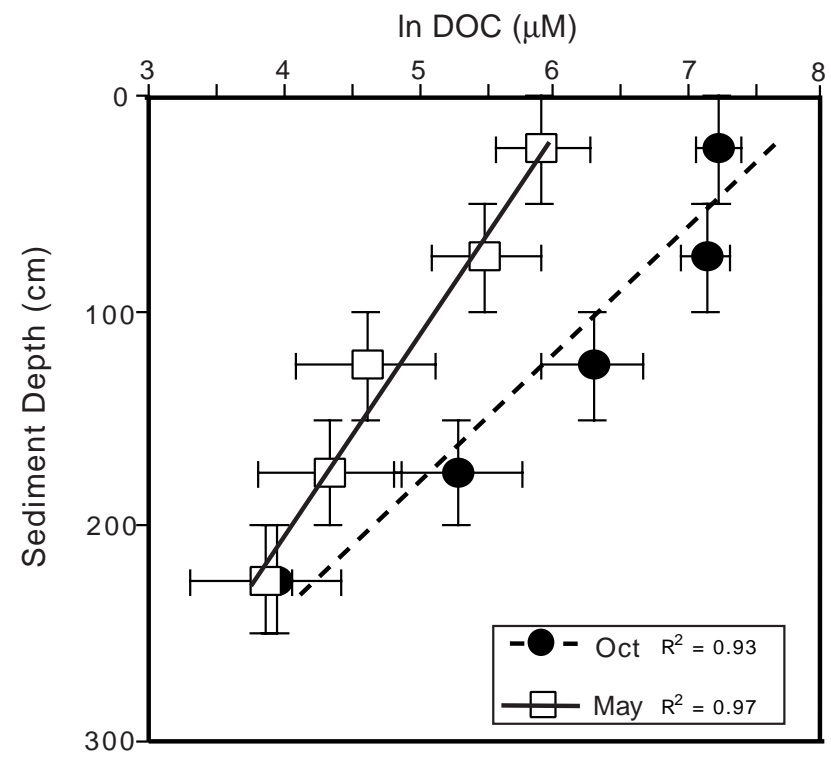

Fig. 3. Porewater dissolved organic carbon concentrations (DOC) in May and October 1997 averaged over depth from Piezometer Clusters r-1, r-2, and r-3. Horizontal error bars denote standard error between the clusters

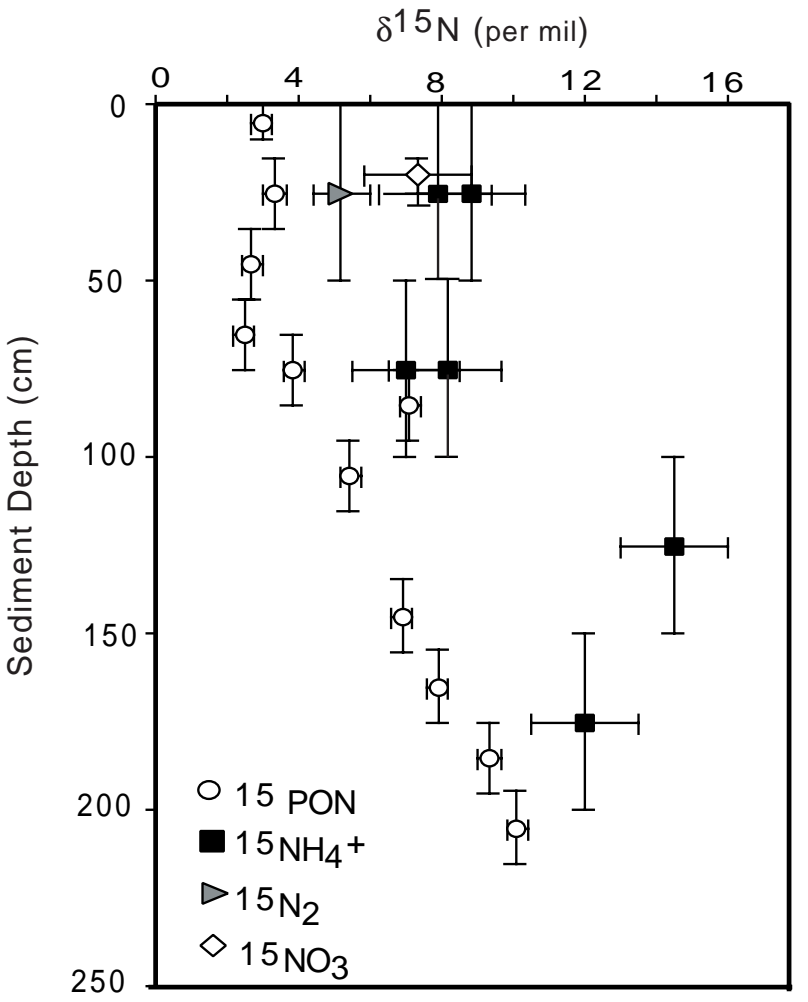

Fig. 4. Natural-abundance $\delta^{15} \mathrm{~N}$ isotope values for DIN $\left(\mathrm{NO}_{3}{ }^{-}\right.$ and $\mathrm{NH}_{4}^{+}$), PON, and $\mathrm{N}_{2}$. Vertical error bars represent the depth interval over which the measurement was derived. Horizontal errors bars for DIN samples represent the standard deviation of replicate distillations of standard solutions; horizontal error bars for $\mathrm{N}_{2}$ denote the average range of duplicate samples; horizontal error bars for PON samples represent the poorest analytical precision observed

values were 3 to $8 \%$-enriched relative to the PON fraction, ranging from 7.1 to $8.8 \%$ within the upper $1 \mathrm{~m}$ (Fig. 4). Nitrate was rarely detected in the piezometers, and a single isotopic value of $7.6 \%$ was determined from a single sample collected at $20 \mathrm{~cm}$ depth. The $\delta^{15} \mathrm{~N}_{-} \mathrm{NO}_{3}{ }^{-}$was within 0.5 to $2 \%$ relative to the $\delta^{15} \mathrm{~N}-\mathrm{NH}_{4}{ }^{+}$values at similar depths. Shallow porewater $\delta^{15} \mathrm{~N}_{2}$ ranged between 5.0 and $5.9 \%$. The isotopic signal of $\mathrm{N}_{2}$ was approximately 4 to $6 \%$ depleted relative to ammonium collected from the same stratum, and enriched 5 to $6 \%$ relative to tidal flooding water $(-0.5 \%)$. The $\delta^{15} \mathrm{~N}_{2}$ signal was within $2 \%$ of the measured $\delta^{15} \mathrm{~N}-\mathrm{NO}_{3}{ }^{-}$value.

\section{Sediment analysis and $\mathbf{N}$ cycling rates}

Shallower sediments in the marsh were more porous, and had the lowest bulk densities. The organic composition of the surface sediments was higher than that found in the deeper sediments, which were more char- 
Table 2. Bulk sediment properties by sediment depth interval from cores collected in August 1996. Averages of $n=2$ cores shown from cores collected within $4 \mathrm{~m}$ of the upland border. Average deviations from means are shown in parentheses

\begin{tabular}{|c|c|c|c|c|c|c|}
\hline $\begin{array}{l}\text { Sediment interval } \\
(\mathrm{cm})\end{array}$ & $\%$ porewater & $\begin{array}{l}\text { Bulk density } \\
\text { (g dry wt } \mathrm{cm}^{-3} \text { ) }\end{array}$ & Porosity & $\%$ organic matter & $\mathrm{C}: \mathrm{N}$ & $\% \mathrm{~N}$ \\
\hline $0-10$ & $58.7(12.2)$ & 0.8 & 0.79 & $18.5(7.0)$ & $17.2(1.5)$ & $0.158(0.096)$ \\
\hline $20-30$ & $32.6(7.2)$ & $1.1(0.04)$ & $0.56(0.20)$ & $4.9(1.10)$ & $16.3(5.6)$ & $0.042(0.039)$ \\
\hline $40-50$ & $20.9(0.05)$ & $1.6(0.09)$ & $0.43(0.02)$ & $1.9(0.02)$ & $20.3(1.5)$ & $0.025(0.006)$ \\
\hline $70-80$ & $18.3(2.9)$ & $1.7(0.15)$ & $0.39(0.04)$ & $1.7(0.30)$ & $12.8(2.4)$ & $0.021(0.002)$ \\
\hline $80-90$ & $19.3(3.4)$ & $1.7(0.20)$ & $0.39(0.04)$ & $1.9(1.1)$ & $12.9(2.1)$ & $0.016(0.004)$ \\
\hline $100-110$ & $17.0(1.4)$ & $1.8(0.20)$ & $0.36(0.01)$ & $1.3(0.5)$ & $9.6(3.9)$ & $0.010(0.003)$ \\
\hline $120-130$ & 17.5 & $1.8(0.12)$ & $0.38(0.03)$ & $1.1(0.20)$ & $8.3(1.3)$ & $0.010(0.0)$ \\
\hline $140-150$ & $17.3(0.49)$ & $1.5(0.08)$ & $0.32(0.03)$ & $1.0(0.20)$ & $8.6(0.8)$ & $0.008(0.001)$ \\
\hline $160-170$ & $17.8(0.93)$ & $1.9(0.31)$ & $0.41(0.04)$ & 0.9 & $10.6(1.1)$ & $0.008(0.002)$ \\
\hline $180-190$ & $18.3(0.63)$ & $1.9(0.29)$ & $0.43(0.04)$ & $0.9(0.40)$ & 8.4 & 0.010 \\
\hline $200-210$ & 17.5 & 1.9 & 0.40 & 0.6 & 8.9 & 0.009 \\
\hline
\end{tabular}

acteristic of aquifer material (Table 2). Decreasing \% organic matter and \% nitrogen with sediment depth were described by logarithmic decay curves with $\mathrm{R}^{2}$ values of 0.81 and 0.84 respectively (data not presented).

Highest extractable $\mathrm{NH}_{4}{ }^{+}$concentrations (up to $900 \mathrm{ng} \mathrm{N} \mathrm{g}{ }^{-1}$ dry wt sediment) were detected in the upper $5 \mathrm{~cm}$ of sediment (Fig. 5). $\mathrm{NH}_{4}{ }^{+}$decreased exponentially with depth to $<5 \mathrm{ng} \mathrm{N} \mathrm{g}{ }^{-1}$ dry wt in the deepest sediments $(>2 \mathrm{~m})$ which constituted the shallow

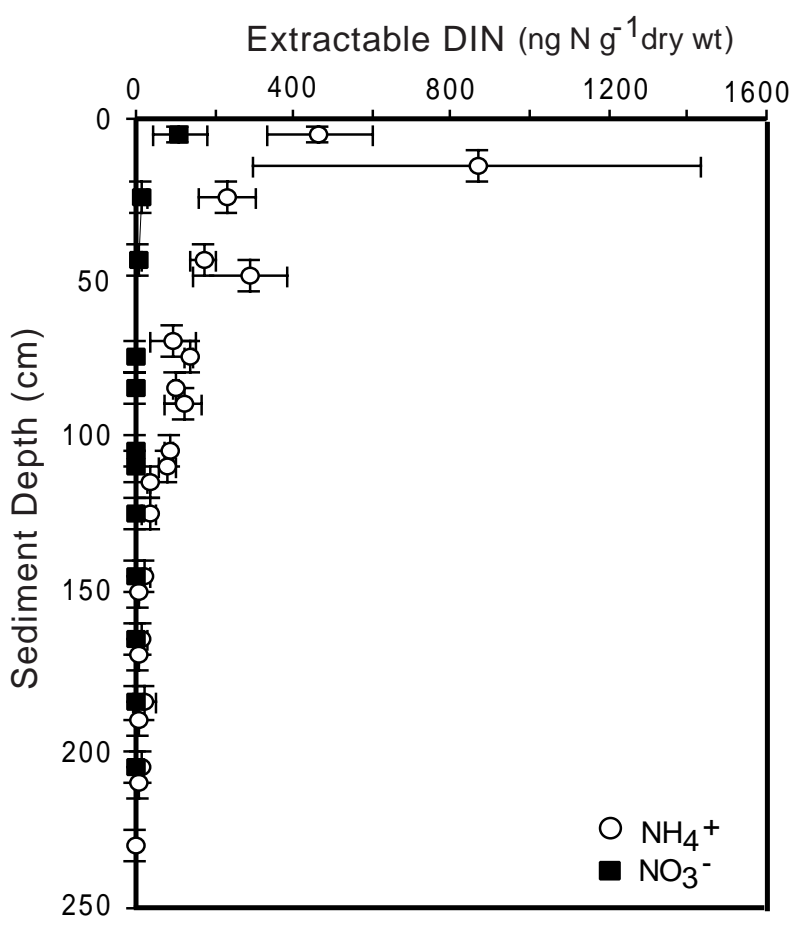

Fig. 5. KCl-extractable DIN pooled from multiple-core locations and times. Vertical error bars denote average depth interval of the sediment subsection extracted, and horizontal error bars indicate the standard error from multiple cores

$$
(2<\mathrm{n}<9)
$$

aquifer. $\mathrm{NO}_{3}{ }^{-}$concentrations were undetectable through most of the cores, with the exception of the upper $5 \mathrm{~cm}$, where concentrations ranged from 20 to $100 \mathrm{ng} \mathrm{N} \mathrm{g}^{-1}$ dry wt sediment.

Eh values in the upland core (Fig 1: Location A) decreased at the water table $(80 \mathrm{~cm})$ and again at $120 \mathrm{~cm}$, but remained positive through the length of the core (Fig. 6). For all other cores, the Eh at the sedimentwater interface was positive, dropped sharply within the

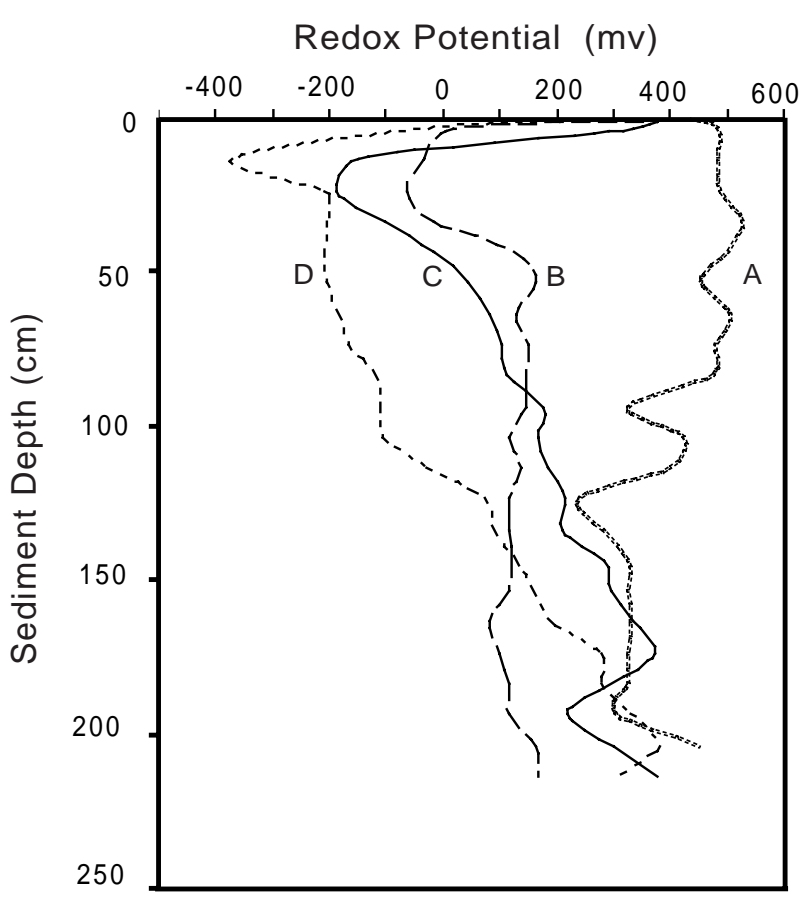

Fig. 6. Redox (Eh) profiles generated for single cores (A to D) collected in August 1996. Cores $A \rightarrow D$ were collected along a transect from the upland into the marsh (see Fig. 1). Eh measurements were taken at $10 \mathrm{~cm}$ intervals and smoothed to generate the profiles 
first $2 \mathrm{~cm}$ of sediment, and rebounded with depth below 20 to $30 \mathrm{~cm}$ depth. By $2 \mathrm{~m}$ depth, Eh in all cores was positive (Fig. 6). The lowest Eh values, as well as the largest shifts in Eh with sediment depth, were observed in cores collected furthest into the marsh (Fig 1: Locations C, D) .

$\mathrm{N}$ cycling rates in all cores were maximal within the upper $30 \mathrm{~cm}$ of sediment, and decayed exponentially with increasing sediment depth (Figs. 7 to 9 ). $\mathrm{R}^{2}$ values for $\log \times \log$-transformed data ranged from 0.76 to 0.96 (Table 3). Rates for MIN, NIT, DNF, and DNRA were not detectable at depths deeper than $150 \mathrm{~cm}$. Depthintegrated rates from 5 to $150 \mathrm{~cm}$ were estimated (Table 3) based on the regression lines in Figs. 8 \& 9 .

Gross mineralization rates were 3 to 20 times higher than nitrification. Highest mineralization (530 $\mathrm{ng} \mathrm{N} \mathrm{g}^{-1}$ dry wt $\mathrm{h}^{-1}$ ) and nitrification ( $24 \mathrm{ng} \mathrm{N} \mathrm{g}{ }^{-1}$ dry wt $\mathrm{h}^{-1}$ ) rates, as well as the depth-integrated rates (11.20 and $2.16 \mathrm{mmol} \mathrm{N} \mathrm{m} \mathrm{N}^{-2} \mathrm{~h}^{-1}$, were observed in the border cores during the May discharge (Figs. 7 \& 8, Table 3). The large changes in depth-integrated rates between May and October were also observed in the border cores. Mineralization was higher by a factor of 12 , and nitrification by a factor of 7 in border cores collected in May relative to those collected in October. Depth-integrated rates of nitrification in border cores were higher than in marsh cores regardless of discharge period, and rates of nitrification were undetectable in the marsh core during low discharge in October. The depth-integrated rate of mineralization was higher in the marsh core (by a factor of 1.4) and in the border core (by a factor of 1.12) in May versus October. Ammonium concentrations were at near steady-state during the incubations. Therefore, $\mathrm{N}$ mineralized in excess of the nitrification rate was assumed to be immobilized.

Of the potential rate measurements, the maximum rate (330 $\mathrm{ng} \mathrm{N} \mathrm{g}^{-1} \mathrm{dry} \mathrm{wt} \mathrm{h}^{-1}$ ), and the depth-integrated rate $\left(6.13 \mathrm{mmol} \mathrm{N} \mathrm{m} \mathrm{N}^{-2} \mathrm{~h}^{-1}\right)$ of DNRA occurred in the border core in May (Figs. 7 \& 9, Table 2). In contrast, potential rates of DNF were 10-fold higher during low discharge in October, when the maximal rate was $944 \mathrm{ng} \mathrm{N} \mathrm{g}^{-1}$ dry wt $\mathrm{h}^{-1}$, and the depth-integrated rate was $17.62 \mathrm{mmol} \mathrm{N} \mathrm{m}^{-2} \mathrm{~h}^{-1}$. The depth-integrated DNF rate was 12 to 20 times higher than that of DNRA during low discharge in October, but was 1.5 to 3 times lower than DNRA in May.

\section{DISCUSSION}

\section{Variation of $\mathbf{N}$ cycling with sediment depth}

\section{Gross mineralization}

The average gross mineralization rate of $216 \pm$ $156 \mathrm{ng} \mathrm{N} \mathrm{g}^{-1}$ dry wt $\mathrm{h}^{-1}$ observed in the shallowest sediments $(0$ to $10 \mathrm{~cm}$ ) is within the range of values reported for other estuarine and coastal marshes, as is the depth-integrated rate of 0.97 to $11.2 \mathrm{mmol} \mathrm{N} \mathrm{m}^{-2}$

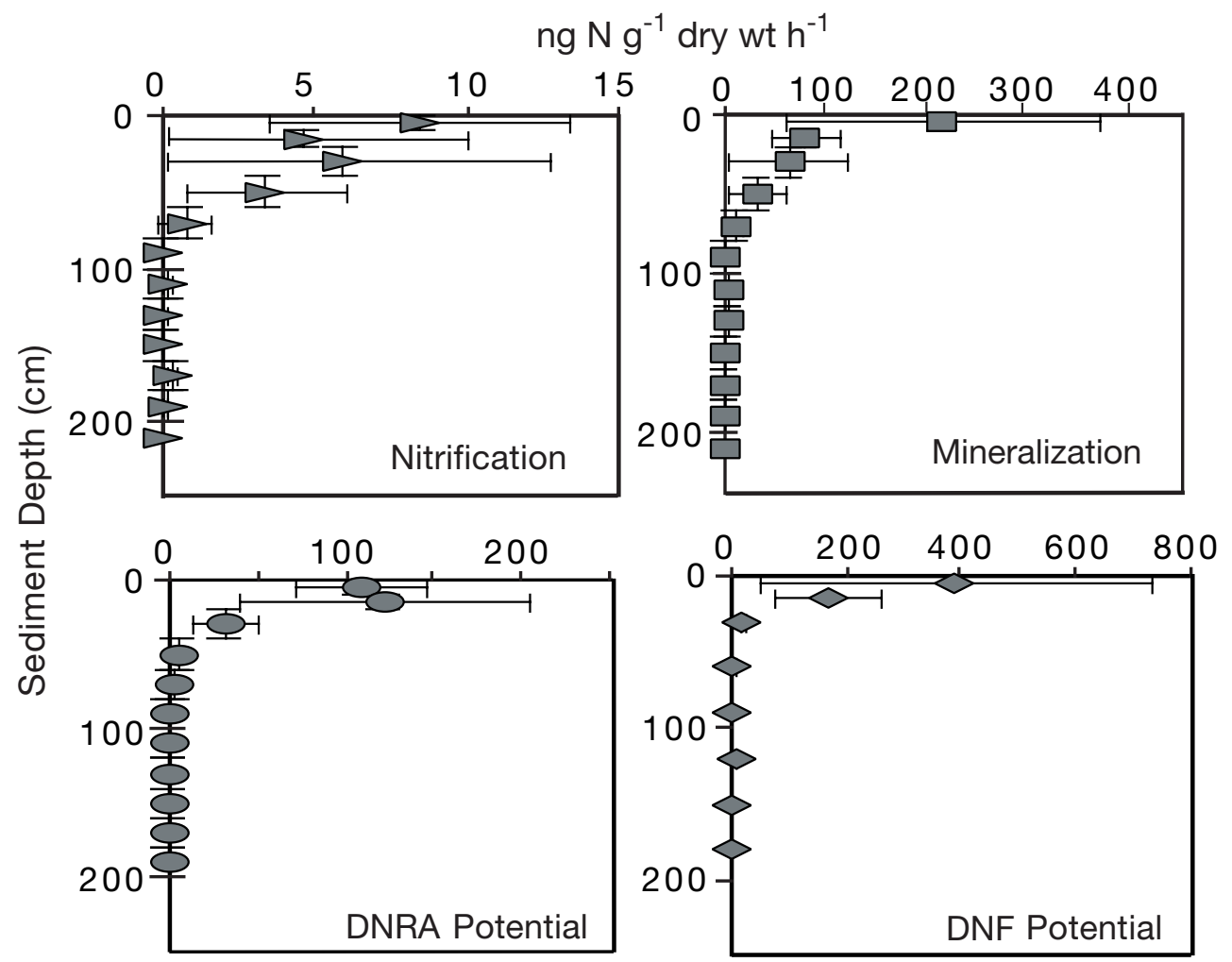

Fig. 7. Summary of gross $\mathrm{N}$ cycling rates and potential rates. All cores and all times ( 4 cores $\times 2$ seasons) for each process were pooled by depth. Means and standard errors are shown 
Fig. 8. Mineralization (MIN) and nitrification (NIT) rates $(\ln \times \ln$ transformed) as a function of sediment depth for border and marsh cores during both seasons

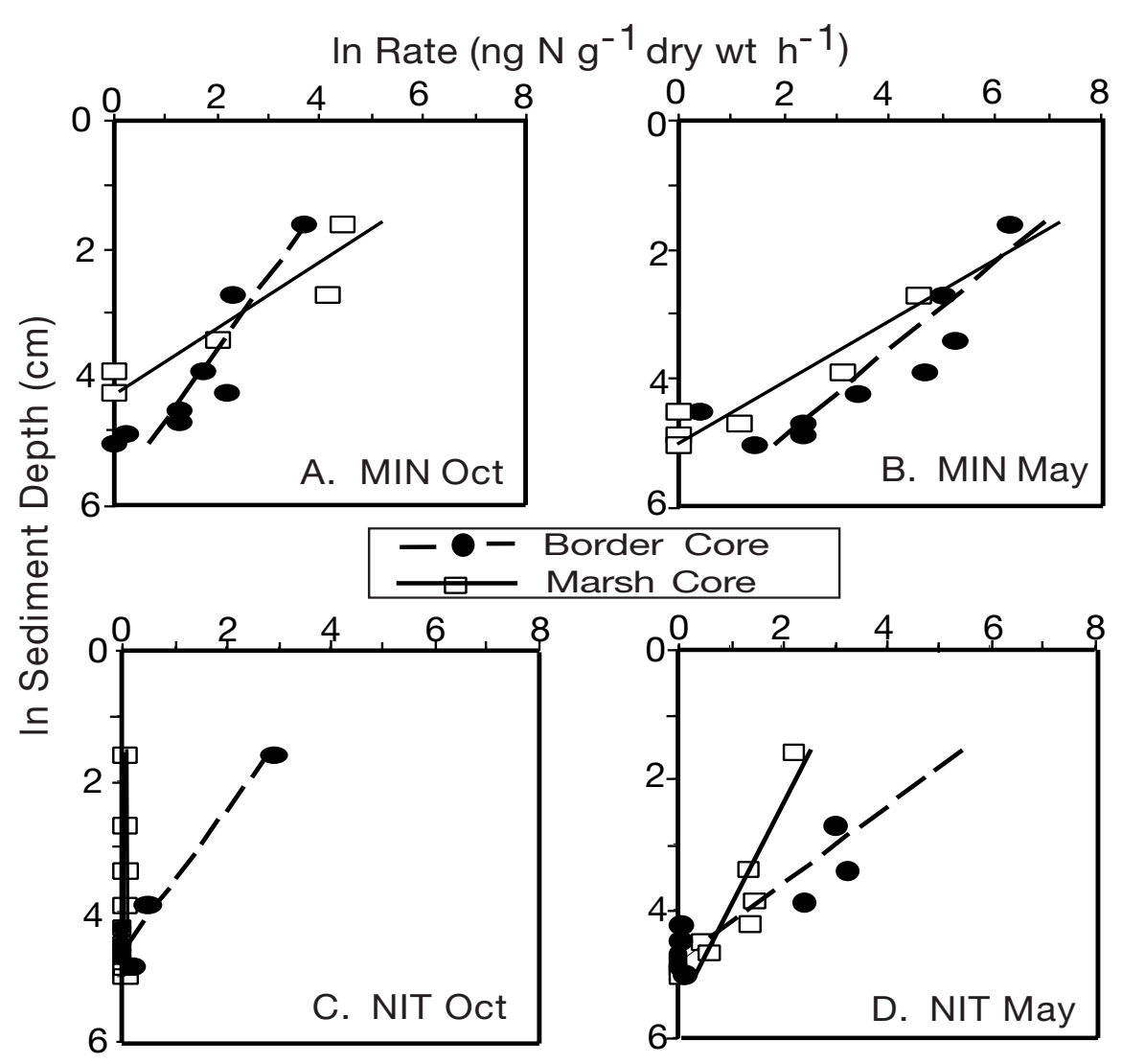

$\mathrm{h}^{-1}$ (Bowden 1984, Anderson et al. 1997). Despite the greater depth used to calculate depth-integrated rates in this study, our results compare favorably to these previously reported values because the majority of the mineralization at Ringfield Marsh occurred in sediments shallower than $50 \mathrm{~cm}$. While higher mineralization rates in the surface sediments and rhizosphere may be in part due to a more direct supply of terminal electron acceptors $\left(\mathrm{O}_{2}, \mathrm{SO}_{4}^{-2}\right.$, or $\left.\mathrm{Fe}^{3+}\right)$ either from the atmosphere, tidal water, or through macrophyte roots (Howes et al. 1984, Nuttle \& Hemond 1988, Roden \& Wetzel 1996, Portnoy \& Giblin 1997), the higher redox potentials below $1.5 \mathrm{~m}$ (Fig. 6) indicate that mineralization in the deeper strata is almost certainly limited by the supply of labile organic matter from above. The \% organic matter, \% sediment organic N, and DOC concentrations decreased with depth more slowly than the decrease in observed mineralization rates. This disparity suggests that a depth-dependent decrease in organic matter lability coincides with declines in total organic matter available for mineralization. Freshly deposited detritus near the sediment surface is more likely to be labile and support higher mineralization rates than older peats or dissolved organics in deeper sediments. The fraction of labile organic matter available for mineralization probably decreases more rap- idly with depth than the bulk DOC profile implies, and may be primarily responsible for the rate of decline in the mineralization rates with increasing depth.

\section{Nitrification}

Maximal shallow-sediment nitrification rates of 2 to $24 \mathrm{ng} \mathrm{N} \mathrm{g}^{-1}$ dry wt $\mathrm{h}^{-1}$ and depth integrated rates of 0.37 to $2.16 \mathrm{mmol} \mathrm{N} \mathrm{m}^{-2} \mathrm{~h}^{-1}$ during low and high discharge periods respectively, were a factor of 3 higher than nitrification rates measured in a North Carolina salt marsh (Thompson et al. 1995), but consistent with rates reported for a New England freshwater marsh, and a Virginia salt marsh (Bowden 1986, Anderson et al. 1997). Nitrification can be either $\mathrm{O}_{2}$ - or $\mathrm{NH}_{4}{ }^{+}$-limited in organic-rich sediments (Henriksen \& Kemp 1988), and the highest nitrification rates at Ringfield were seen in surface sediments possessing the highest $\mathrm{NH}_{4}{ }^{+}$and nearest the atmospheric source of $\mathrm{O}_{2}$. At depths between 10 and $100 \mathrm{~cm}$, extractable $\mathrm{NH}_{4}{ }^{+}$concentrations exceeded $100 \mathrm{ng} \mathrm{N} \mathrm{g}{ }^{-1}$ dry wt, but DO was undetectable, suggesting $\mathrm{O}_{2}$ limitation of nitrification. Below $1.5 \mathrm{~m}$, DO concentrations and redox potential were sufficiently high to support nitrification, yet none was observed indicating that deeper sediments re- 


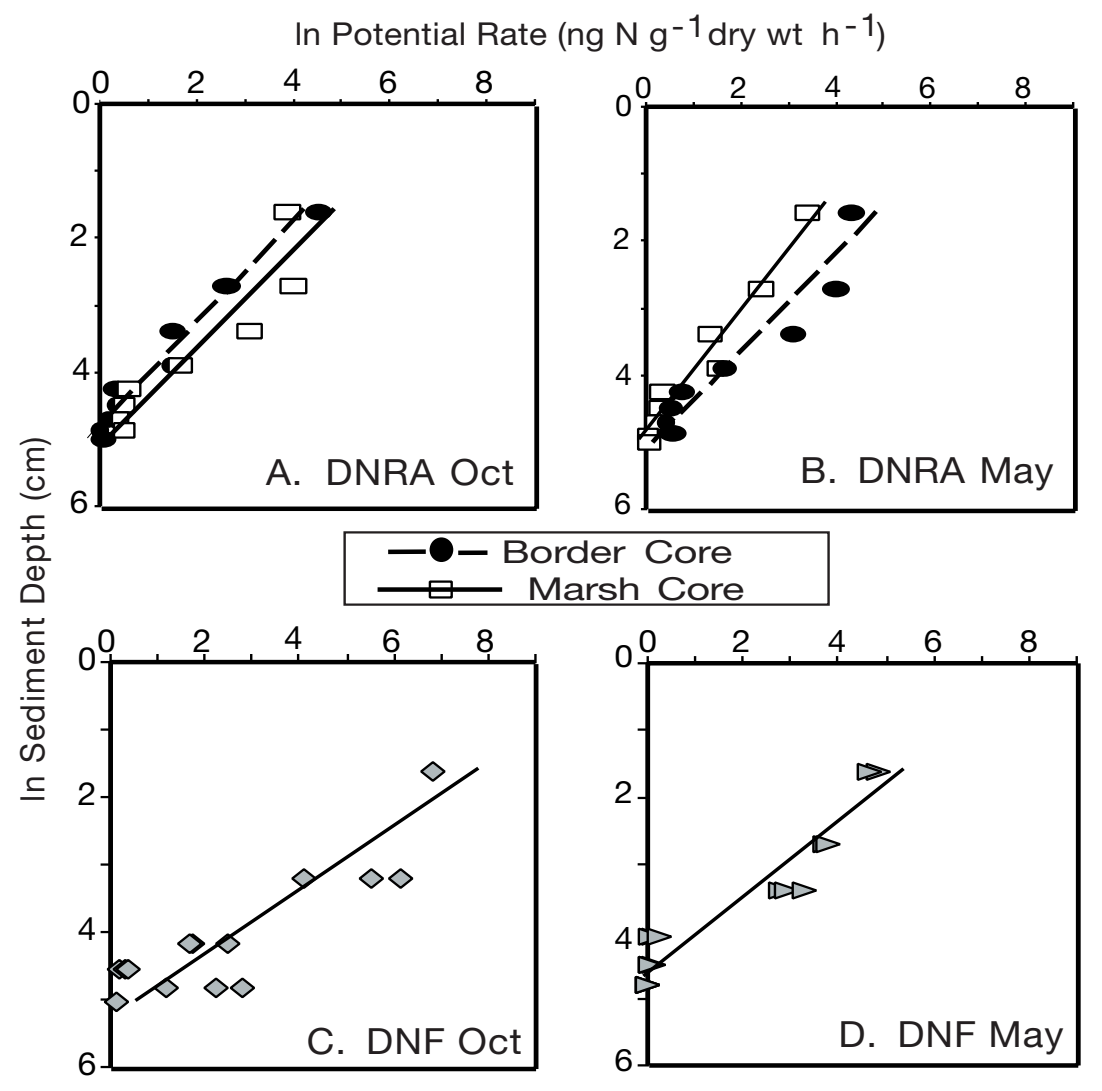

Fig. 9. Potential denitrification (DNF) and dissimilatory nitrate reduction to ammonium (DNRA) rates (ln $\times \ln$-transformed) as a function of depth for border and marsh cores (DNRA) during both seasons. Shaded symbols for the DNF plots indicate results from cores collected midway between $\mathrm{B}$ and $\mathrm{C}$ coring locations

$\mathrm{NO}_{3}{ }^{-}$, it is assumed that the enrichment of the porewater $\delta^{15} \mathrm{~N}_{2}$ results from the addition of isotopically heavier denitrified $\mathrm{N}_{2}$ produced via $\mathrm{PON} \rightarrow \mathrm{NH}_{4}{ }^{+} \rightarrow \mathrm{NO}_{3}{ }^{-} \rightarrow \mathrm{N}_{2}$. Assuming minimal isotopic fractionation during $\mathrm{NO}_{3}{ }^{-} \rightarrow \mathrm{N}_{2}$, (because $\mathrm{NO}_{3}{ }^{-}$is almost completely consumed), the $\delta^{15} \mathrm{~N}$ of denitrified $\mathrm{N}_{2}$ would be equal to that of the $\mathrm{NO}_{3}{ }^{-}(7.6 \%)$. Therefore, the observed porewater $\delta^{15} \mathrm{~N}_{2}(5.8 \%$ ) results from a mixing of the denitrified $\mathrm{N}_{2}$ $\left(\mathrm{DNF}-\mathrm{N}_{2}\right)$, and the $\mathrm{N}_{2}$ dissolved in infiltrating estuarine water in a ratio of 3:1. Given a tidal infiltration flux for the site of $2.6 \mathrm{l} \mathrm{m}^{-2} \mathrm{~d}^{-1}$ and a steadystate dissolved $\mathrm{N}_{2}$ concentration of $600 \mu \mathrm{M}$ (Tobias 1999), the rate of dissolved $\mathrm{N}_{2}$ input to porewater is $1.5 \mathrm{mmol} \mathrm{N}_{2} \mathrm{~m}^{-2} \mathrm{~d}^{-1}$. Using an isotope mixing balance between tidal dissolved $\mathrm{N}_{2}$ and $\mathrm{DNF}-\mathrm{N}_{2}$, a production rate of DNF- $\mathrm{N}_{2}$ can be estimated at $0.39 \mathrm{mmol} \mathrm{N} \mathrm{m} \mathrm{N}^{-2} \mathrm{~h}^{-1}$. This rate represents a minimum nitrification rate necessary to support coupled nitrification-denitrification, and is roughly equal to the smallest depth-integrated NIT rate calculated for the border cores (Table 3). Together, the sediment core and isotopic evidence suggest that in zones of fringing marshes nearest the upland border, nitrifica-

ceived inadequate transport of $\mathrm{NH}_{4}{ }^{+}$from upper sediments. Unlike most organic-rich sediments where nitrification is limited by oxygen penetration to sediment depths of 0 to $2 \mathrm{~cm}$ (Jensen et al. 1994), measurable rates at Ringfield were observed to greater depths $(30$ to $100 \mathrm{~cm}$ ) than previously reported. Despite lower rates of nitrification in sediments deeper than $10 \mathrm{~cm}$, the integration of these rates through the sediment profile accounted for 34 to $77 \%$ of the total depth-integrated rate. This suggests that depth-integration of nitrification rates over only the top few centimeters in fringing marshes may underestimate the total nitrification in these types of systems.

Although the ratio of nitrification to mineralization in the border cores (1:4) was larger than the 1:10 ratio reported in other studies (Anderson et al. 1997), the magnitude of the nitrification rate is corroborated by combining the natural-abundance stable $\delta^{15} \mathrm{~N}$ data (Fig. 4) with estimates of tidal water infiltration for the site (Tobias 1999). Average porewater $\delta^{15} \mathrm{~N}_{2}$ was $5.8 \%$ compared to a $\delta^{15} \mathrm{~N}_{2}$ of $-0.5 \%$ measured in York River water. Because York River estuary water contains low tion may be a more important fate for $\mathrm{NH}_{4}{ }^{+}$, and when coupled to denitrification represents a greater $\mathrm{N}$-export term than previously observed in other marshes.

\section{Potential nitrate reduction rates}

Compared with literature values for high $\mathrm{NO}_{3}{ }^{-}$or $\mathrm{NO}_{3}^{-}$-amended marsh environments, the observed depth-integrated potential DNF rates of 1.7 to $10.5 \mathrm{mmol} \mathrm{N} \mathrm{m} \mathrm{N}^{-2} \mathrm{~h}^{-1}$ are higher than denitrification rates typically reported for freshwater and salt marshes ( 0.71 to $7.85 \mathrm{mmol} \mathrm{N} \mathrm{m}^{-2} \mathrm{~h}^{-1}$ ), but are close to the median of rates reported for estuarine and coastal sediments (Koike \& Sorenson 1988, Seitzinger 1988, Howes et al. 1996). Depth-integrated potential DNRA rates of 1.37 to $4.23 \mathrm{mmol} \mathrm{m}^{-2} \mathrm{~h}^{-1}$ were consistent with the range $\left(0.8\right.$ to $\left.50 \mathrm{mmol} \mathrm{N} \mathrm{m} \mathrm{N}^{-2} \mathrm{~h}^{-1}\right)$ of rates observed in estuarine sediments (Koike \& Sorenson 1988).

Although reduced iron and sulfur compounds can act as electron donors for both denitrification and DNRA, DOC is thought to be the primary source of 
Table 3. Summary of regressions and depth-integrated rates for all core experiments. Data were fit with a power function in the form of $y=[\exp (b)] \cdot\left(x^{\mathrm{m}}\right)$, where $y$ is the rate of the selected $\mathrm{N}$ cycling process (ng $\mathrm{N} \mathrm{g}^{-1}$ dry wt $\left.\mathrm{h}^{-1}\right), x$ is sediment depth $(\mathrm{cm}), b$ is the natural log of the maximal rate at $1 \mathrm{~cm}$ depth as determined from the model, and $m$ is the slope of the least-squares linear fit of ln depth vs ln rate plots (Figs. 8 \& 9). Depth-integrated rates $\left(\mathrm{mmol} \mathrm{N} \mathrm{m} \mathrm{N}^{-2} \mathrm{~h}^{-1}\right.$ ) were calculated by converting sediment depth to mass ( $g$ dry wt) using bulk densities in Table 2 and assuming an area of $1 \mathrm{~m}^{2}$, followed by the integration of the rate (ng $\mathrm{N} \mathrm{g}^{-1}$ dry wt $\mathrm{h}^{-1}$ ) vs sediment mass ( $\mathrm{g}$ dry wt) with respect to sediment mass from 5 to $150 \mathrm{~cm}$ depth. Error in the depth integrated rate was estimated by integrating a plot of the root square of the residuals from the regression vs sediment mass with respect to sediment mass, and is shown in parentheses

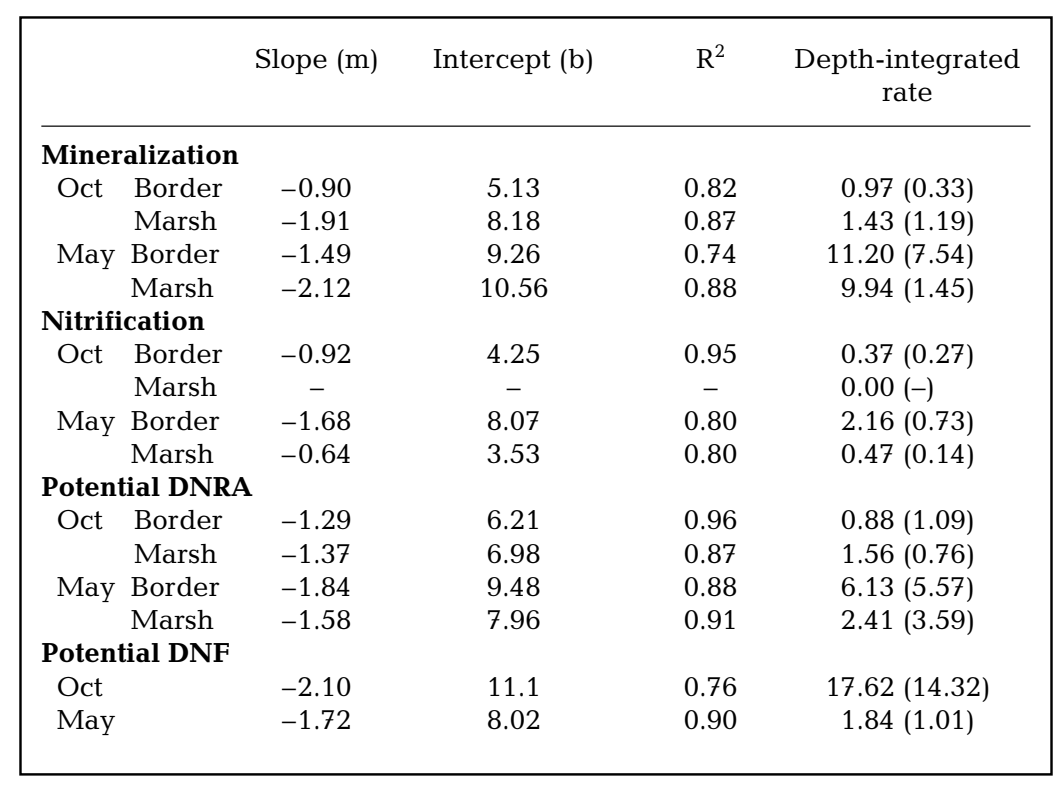

the $\mathrm{N}$ cycling rates significantly. However, as a result of porewater flushing with fresh oxic groundwater, the DO flux to the marsh subsurface was higher, and the salinity, sulfide, and DOC of porewaters was lower in May. Groundwater delivered a DO flux of $27 \mu \mathrm{mol} \mathrm{O}_{2} \mathrm{~m}^{-2} \mathrm{~h}^{-1}$ into the upper $1 \mathrm{~m}$ of marsh near the upland border in May. Porewater salinity was reduced by 30 to $70 \%$, and sulfide by approximately 50 to $300 \mu \mathrm{M}$ in May versus October.

\section{Mineralization}

Although few studies have examined seasonal variations in gross mineralization in marsh sediments, peak rates tend to occur in fall when plants scenesce and the supply of fresh macrophyte detritus increases (Bowden 1984, Anderson et al. 1997, Neubauer et al. 2000). In contrast, and despite higher porewater DOC concentrations, mineralization rates in the Ringfield marsh were 10-fold lower in October than in May. Although sediment mineralization rates can also be stimulated by an increased supply of

electrons fueling $\mathrm{NO}_{3}{ }^{-}$reduction in organic-rich sediments (Tiedje 1988). The maximal potential DNF and DNRA rates measured in the shallow sediments in this study are coincident with peak DOC concentrations near the surface (Fig. 3). As with mineralization, potential rates of both DNF and DNRA decreased more rapidly with increasing depth than DOC concentrations, indicating the importance of organic matter lability in controlling the reduction of nitrate as well as mineralization. Below $1.5 \mathrm{~m}$, however, in situ DO concentrations and redox potential were sufficiently high to inhibit DNF and DNRA regardless of labile DOC availability (Currin et al. 1996). Both DO and labile DOC distribution restricts $\mathrm{NO}_{3}{ }^{-}$reduction to the upper $1 \mathrm{~m}$ of the marsh.

\section{Variation in $\mathbf{N}$ cycling with seasonal discharge}

Temperature, pH, salinity, sulfide, DOC, and oxygen availability can all be expected to affect rates of the $\mathrm{N}$ cycling processes we studied. Porewater temperature and $\mathrm{pH}$ were within $\pm 0.2^{\circ} \mathrm{C}$ and \pm 0.2 respectively, between study periods, and not likely to have affected terminal electron acceptors $\left(\mathrm{SO}_{4}{ }^{-2}, \mathrm{O}_{2}\right.$ i Hansen \& Blackburn 1991, Portnoy \& Giblin 1997, Holmer 1999), lower porewater salinity (i.e. a decreased supply of $\mathrm{SO}_{4}^{-2}$ ) at Ringfield accompanied the May period of high mineralization. Even though groundwater was a source of $\mathrm{O}_{2}$ in May, the estimated oxygen flux to the marsh subsurface could stoichiometrically account for $<1 \%$ of the observed increase in $\mathrm{N}$ mineralization at that time. This lack of oxygen effect is in agreement with the results of Lee (1992) and Moore et al. (1992), who found that $\mathrm{O}_{2}$ supply had only a small influence on the rates of organic matter degradation. It is possible however, that the May groundwater $\mathrm{O}_{2}$ flux affected mineralization indirectly, in excess of what $\mathrm{C}: \mathrm{N}: \mathrm{O}$ stoichiometry predicted. Intermittent reoxidation of sediments and increased porewater mixing could result from the increased advection of water through the subsurface. High advection velocity in May could accelerate delivery of substrates to active microsites, and fluctuations in discharge in response to tides and discrete precipitation events may cause alternating reduced (porewater) and oxidized (groundwater) conditions in sediments located in the discharge zone. These processes may be analogous to the sediment 
reoxidation and enhanced metabolite mixing that results from sediment resuspension and catalyzes the high mineralization rates observed in deltaic sediments (Aller 1998). While groundwater may supply electron acceptors $\left(\mathrm{CO}_{2}, \mathrm{SO}_{4}{ }^{-2}\right)$ in addition to $\mathrm{O}_{2}$, the concentrations of these compounds in groundwater are small relative to the amount of $\mathrm{SO}_{4}{ }^{-2}$ supplied by tidal water in October. In all, it is unlikely that the increased groundwater flux of electron acceptors during May was solely responsible for the higher mineralization rates observed. Perhaps the increased mineralization in May represents a physiological response of heterotrophs to lower salinity similar to that observed in nitrifiers (Rysgaard et al. 1999).

\section{Nitrification}

The 6-fold increase in the depth-integrated nitrification rates during the May discharge resulted both from an increase in the maximum rate in the top $10 \mathrm{~cm}$, and the depth to which measurable rates were encountered. The calculated groundwater-derived $\mathrm{O}_{2}$ flux at high discharge in May (assuming a nitrification $\mathrm{O}_{2}: \mathrm{N}$ stoichiometry of 1.5) could support a nitrification rate of $20.25 \mu \mathrm{mol} \mathrm{N} \mathrm{m} \mathrm{N}^{-2} \mathrm{~h}^{-1}$ or only $4.5 \%$ of the observed inter-season rate difference. Additionally, this estimate requires that all the new $\mathrm{O}_{2}$ be consumed by nitrification, which is unlikely given the high rates of mineralization (Jensen et al. 1994). Oxygen pumping resulting from higher rates of macrophyte production in May could have supplied additional $\mathrm{O}_{2}$ to shallow sediments (Howes et al. 1981), but this flux cannot account for elevated rates below the rhizosphere. While the groundwater $\mathrm{O}_{2}$ flux apparently contributes a small percentage of the nitrification $\mathrm{O}_{2}$ demand of the sediments from 0 to $50 \mathrm{~cm}$, it is proportionally more important to sediments below the rhizosphere. The rates below $50 \mathrm{~cm}$ account for an average of $30 \%$ of the total depth-integrated nitrification rates in both October and May, and the groundwater $\mathrm{O}_{2}$ flux could support 9 to $36 \%$ of the inter-season difference in the depthintegrated rate between 50 and $120 \mathrm{~cm}$. Although, the groundwater $\mathrm{O}_{2}$ flux is potentially important to zones of nitrification which lack a direct atmospheric flux of $\mathrm{O}_{2}$ (e.g. deeper marsh sediments or subtidal environments), it cannot solely explain the elevated depthintegrated nitrification rates encountered in May.

Sulfide can inhibit nitrification by up to $75 \%$ at $60 \mu \mathrm{M}$ and completely at $100 \mu \mathrm{M}$ (Joye \& Hollibaugh 1995). The average between-season difference in $\mathrm{H}_{2} \mathrm{~S}$ concentrations in the upper $1 \mathrm{~m}$ of marsh sediment exceeded $100 \mu \mathrm{M}$ (Fig. 2). This change in concentration may have sufficiently suppressed nitrification rates to the observed levels in October and specifically led to the undetectable nitrification rate in the marsh core where the highest $\mathrm{H}_{2} \mathrm{~S}$ concentrations occurred.

Salinity effects on nitrification rates either through direct physiological constraints, or by mediating exchangeable ammonium, have been documented in freshwater and saline systems (Jones \& Hood 1980, Seitzinger 1988, Gardner et al. 1991, Seitzinger et al. 1991). The lower nitrification rates encountered in October were coincident with a 4-fold increase in porewater salinity. The October decline in nitrification was consistent with previously observed decreases in nitrification induced by salinity increases within the seasonal range observed in Ringfield porewaters (Rysgaard et al. 1999). We suggest that porewater salinity reduction in May acted in concert with changes in $\mathrm{H}_{2} \mathrm{~S}$ and increased $\mathrm{O}_{2}$ delivery to deeper sediments to produce the seasonal shifts in nitrification rates.

\section{Potential nitrate reduction}

Because both DNF and DNRA derive electrons from DOC, we expected maximal rates for both processes to occur in October when DOC was higher. Additionally, because experimental $\mathrm{NO}_{3}{ }^{-}$additions were constant between seasons, we expected DNRA to be favored over DNF as a result of the decreased $\mathrm{NO}_{3}{ }^{-}$:DOC ratio in October (King \& Nedwell 1985, Tiedje 1988). While the depth-integrated DNF rate was 10-fold larger in October, DNRA rates were 2 to 3.5-fold higher in May (Table 3), when DOC concentrations were lowest. Thus, the ratio of DNF:DNRA increased from 0.6 to 16 from May to October despite the higher DOC and $\mathrm{H}_{2} \mathrm{~S}$ in October. Based on our current understanding of the factors regulating DNF versus DNRA rates, it is difficult to identify any environmental difference measured at our site that would simultaneously increase DNRA and decrease DNF during high discharge. We believe that the observed seasonal changes in DNF and DNRA may have resulted from seasonal shifts in microbial populations or changes in the source and lability of the DOC substrate. The fermentative organisms thought to perform DNRA may have different carbon requirements than denitrifiers, and their growth could be supported by exudates from actively growing macrophytes in May which have scenesced in the fall. Alternately, the fermenters may require an organic carbon source that is produced as an intermediate during mineralization which was at its peak during high discharge. Bulk DOC measurements are not reflective of changes in the DOC quality, and offer little insight regarding substrates supporting DNF and DNRA. DOC characterization and the effects of specific DOC components on DNF and DNRA should be a focus of future work. 


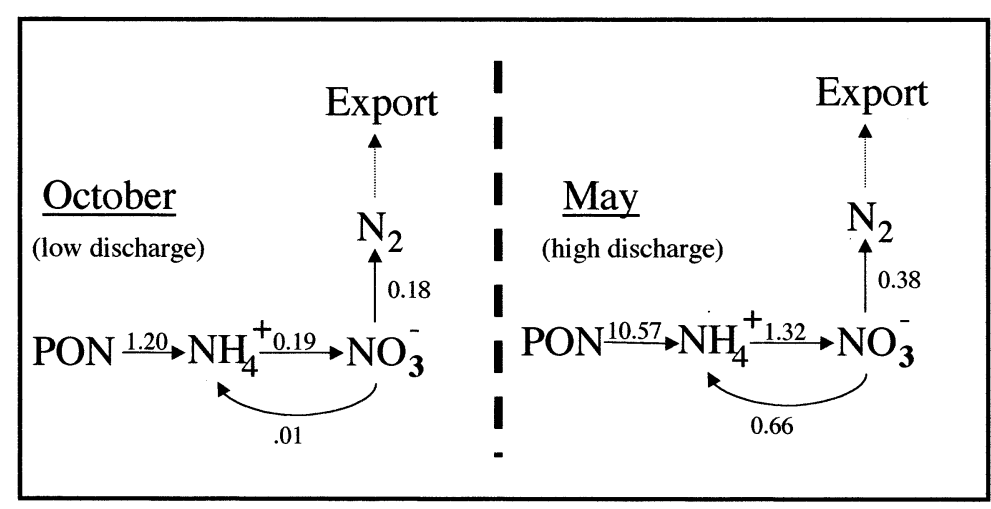

Fig. 10. Net export effect of seasonal changes in MIN, NIT, DNF, and DNRA. $\mathrm{N}$ transfer rates are reported in mmol N m $\mathrm{N}^{-2} \mathrm{~h}^{-1}$. NIT and MIN rates are the average of border and marsh cores. $\mathrm{NO}_{3}^{-} \rightarrow \mathrm{NH}_{4}{ }^{+}=($avg DNRA rate/[avg DNRA rate + avg DNF rate] $) \times$ NIT. $\mathrm{NO}_{3}^{-} \rightarrow \mathrm{N}_{2}=([$ avg DNF rate]/[avg DNRA rate + avg DNF rate]) $\times$ NIT
Acknowledgements. We would like to thank the 4 anonymous reviewers whose comments greatly improved this paper. We express our thanks to the many students and colleagues who assisted with various aspects of the project: David Fugate, David Miller, Scott Neubauer, Chris Buzzelli, Tim Dellapena, Betty Neikirk, Peter Raymond, and Matt Church for their assistance in the field and laboratory; as well as Jud Harvey, USGS, Reston, VA; David Harris, University of California, Davis; Howard Kator, Virginia Institute of Marine Science. This work was supported by grants from the National Science Foundation (DEB-9120183, DEB-9411974, DEB9520819, and OCE-9521170), USDA Forest Service PSW-97-0036CA, and the generosity of Chuck Rafkind at the Colonial National Historical Park. VIMS contribution no. 2356.

\section{Net seasonal effect on $\mathbf{N}$ recycling and export}

Seitzinger (1994) demonstrated that the tight coupling between the supply of $\mathrm{NH}_{4}{ }^{+}$from mineralization and nitrification/denitrification rates resulted in increased $\mathrm{N}$ export via denitrification from many riparian wetlands. As suggested by undetectable porewater $\mathrm{NO}_{3}{ }^{-}$stocks, and the isotopic enrichment of porewater $\delta^{15} \mathrm{~N}_{2}$, this coupling is similarly strong in the Ringfield marsh. In May, however, the nitrification rate increased 6-fold but the DNF:DNRA ratio (0.6) was lower than in October, resulting in only a 2-fold increase in $\mathrm{N}$ export (0.38 mmol $\left.\mathrm{N} \mathrm{m}^{-2} \mathrm{~h}^{-1}\right)$ via DNF (Fig. 10). The increased DNRA rates that accompanied the higher mineralization and nitrification rates at high discharge resulted in the retention of a higher proportion of the nitrified $\mathrm{N}$ in the system as $\mathrm{NH}_{4}{ }^{+}$(Aziz \& Nedwell 1986). Without the increase in DNRA during May, net $\mathrm{N}$ loss would be approximately $0.94 \mathrm{mmol} \mathrm{m}^{-2} \mathrm{~h}^{-1}$. Because DNRA increased and DNF decreased in May, the more rapid mineralization and nitrification of $\mathrm{N}$ encountered during the spring discharge were not coincident with an equivalently large export of $\mathrm{N}$ out of the marsh via denitrification. The internal N cycling was higher during high discharge, while the relative proportion of $\mathrm{N}$ exported from the marsh (DNF) to the total $\mathrm{N}$ turnover was greater during low discharge.

Discharge at the coastal margin is not restricted to fringing wetlands, and shifts in $\mathrm{N}$ cycling may likewise occur in subtidal sediments receiving fresh groundwater discharge. Based on the results of this study, and given a sufficient areal extent of discharge, we suggest that groundwater flow may be an important seasonal regulator of $\mathrm{N}$ cycling and $\mathrm{N}$ retention in some intertidal and nearshore subtidal estuarine habitats.

\section{LITERATURE CITED}

Aller R (1998) Mobile deltaic and continental shelf muds as suboxic, fluidized bed reactors. Mar Chem 61:143-155

Anderson IC, Tobias CR, Neikirk BB, RL Wetzel (1997) Development of a process-based nitrogen mass balance model for a Virginia Spartina alterniflora saltmarsh: implications for net DIN flux. Mar Ecol Prog Ser 159:13-27

Aziz S, Nedwell DB (1986) The nitrogen cycle of an east coast, U.K. saltmarsh. II. Nitrogen fixation, nitrification, denitrification, tidal exchange. Estuar Coast Shelf Sci 22: 689-704

Benson MB, Krause D (1984) The concentration and isotopic fractionation of oxygen dissolved in freshwater and seawater in equilibrium with the atmosphere. Limnol Oceanogr 29:620-627

Bowden WB (1984) A nitrogen-15 isotope dilution study of ammonium production and consumption in a marsh sediment. Limnol Oceanogr 29:1004-1015

Bowden WB (1986) Nitrification, nitrate reduction, and nitrogen immobilization in a tidal freshwater wetland. Ecology 67:88-99

Bremner JM, Keeney DR (1966) Determination and isotoperatio analysis of different forms of nitrogen in soilsexchangeable ammonium, nitrate, and nitrite by extraction-distillation methods. Proc Soil Sci Soc Am 30:577-582

Brooks PD, Stark JM, McInteer BB, Preston T (1989) Diffusion method to prepare soil extracts for automated nitrogen-15 analysis. Proc Soil Sci Soc Am 53:1707-1711

Brunet RC, Garcia-Gil LJ (1996) Sulfide-induced dissimilatory nitrate reduction to ammonia in anaerobic freshwater sediments. FEMS Microbiol Ecol 21: 131-138

Childers DL (1994) Fifteen years of marsh flumes - a review of marsh-water column interaction in Southeastern USA estuaries. In: Mitsch W (ed) Global wetlands. Elsevier Press, Amsterdam, p 277-294

Childers DL, Day JW (1988) Direct quantification of nutrient and material fluxes between microtidal gulf coast wetlands and the estuarine water column. Estuar Coast Shelf Sci 36:105-131

Cline JD (1969) Spectrophotometric determination of hydrogen sulfide in natural waters. Limnol Oceanogr 14: $454-458$ 
Currin CA, Joye SB, Paerl HW (1996) Diel rates of $\mathrm{N}_{2}$-fixation and denitrification in a transplanted Spartina alterniflora marsh: implications for N-flux dynamics. Estuar Coast Shelf Sci 42:597-616

Dai T, Wiegert RG (1996) A field study of photosynthetic capacity and its response to nitrogen fertilization in Spartina alterniflora. Estuar Coast Shelf Sci 45:273-283

Davidson EA, Stark JM, Firestone MK (1990) Microbial production and consumption of nitrate in an annual grassland. Ecology 71:1968-1975

DeLaune RD, Smith CJ, Patrick WH (1983) Nitrogen losses from a Louisiana Gulf Coast salt marsh. Estuar Coast Shelf Sci 17:133-141

Fetter CW (1993) Contaminant hydrogeology. Macmillan Publishing, London

Gardner WS, Seitzinger SP, Malczyk JM (1991) The effects of sea salts on the forms of nitrogen released from estuarine and freshwater sediments: does ion pairing affect ammonium flux? Estuaries 14:157-166

Glibert PM, Capone DG (1993) Mineralization and assimilation in aquatic, sediment, and wetland systems. In: Knowles R, Blackburn TH (eds) Nitrogen isotope techniques. Academic Press, New York, p 243-272

Hansen LS, Blackburn TH (1991) Aerobic and anaerobic mineralization of organic material in marine sediment microcosms. Mar Ecol Prog Ser 75:283-291

Henriksen K, Kemp M (1988) Nitrification in estuarine and coastal marine sediments. In: Blackburn $\mathrm{TH}$, Sorensen J (eds) Nitrogen cycling in coastal marine environments. John Wiley \& Sons, London, p 207-249

Hines ME, Knollmeyer SL, Tugel JB (1989) Sulfate reduction and other sedimentary biogeochemistry in a northern New England salt marsh. Limnol Oceanogr 34:578-590

Holmer M (1999) The effect of oxygen depletion on aerobic organic matter degradation in marine sediments. Estuar Coast Shelf Sci 48:383-390

Howes BL, Howarth RW, Teal JM, Valiela I (1981) Oxidationreduction potentials in a salt marsh: spatial patterns and interactions with primary production. Limnol Oceanogr 26:350-360

Howes BL, Dacey JWH, King GM (1984) Carbon flow through oxygen and sulfate reduction pathways in salt marsh sediments. Limnol Oceanogr 29:1037-1051

Howes BL, Weiskel PK, Goehringer DD, Teal JM (1996) Interception of freshwater and nitrogen transport from uplands to coastal waters: the role of saltmarshes. In: Nordstrom KF, Roman CT (eds) Estuarine shores: evolution, environments and human alterations. John Wiley \& Sons, London, p 287-310

Jensen K, Sloth NP, Risgaard-Peterson N, Rysgaard S, Revsbech NP (1994) Estimation of nitrification and denitrification from microprofiles of oxygen and nitrate in model sediment systems. Appl Environ Microbiol 60:2094-2100

Jones RD, Hood MA (1980) Effects of temperature, pH, salinity, and inorganic nitrogen on the rate of ammonium oxidation by nitrifiers isolated from wetland environments. Microb Ecol 6:39-347

Joye SB, Hollibaugh JT (1995) Influence of sulfide inhibition of nitrification on nitrogen regeneration in sediments. Science 270:623-625

King D, Nedwell DB (1985) The influence of nitrate concentration upon the end-products of nitrate dissimilation by bacteria in anaerobic salt marsh sediment. FEMS Microbiol Ecol 31:23-28

Knowles R (1990) Acetylene inhibition technique: development, advantages, and potential problems. In: Revsbech NP, Sorenson J (eds) Denitrification in soil and sedi- ment. Kluwer Academic/Plenum Publishers, New York, p 151-166

Koike I, Sorenson J (1988) Nitrate reduction and denitrification in marine sediments. In: Blackburn $\mathrm{T}$, Sorenson $\mathrm{J}$ (eds) Nitrogen cycling in the coastal marine environments. John Wiley \& Sons, London, p 251-270

Lee C (1992) Controls on organic carbon preservation: the use of stratified water bodies to compare intrinsic rates of decomposition in oxic and anoxic systems. Geochim Cosmochim Acta 56:3323-3335

Moore PA, Reddy KR, Graetz DA (1992) Nutrient transformations in sediments as influenced by oxygen supply. J Environ Qual 21:387-393

Morris JT (1980) The nitrogen uptake kinetics of Spartina alterniflora in culture. Ecology 61:1114-1121

Neubauer SC, Miller WD, Anderson IC (2000) Carbon cycling in a tidal freshwater marsh ecosystem: a carbon gas flux study. Mar Ecol Prog Ser 199:13-30

Nuttle WK, Hemond HF (1988) Salt marsh hydrology: implications for biogeochemical fluxes to the atmosphere and estuaries. Global Biogeochem Cycles 2:91-114

Patrick WH, Gambrell RP, Faulkner SP (1996) Redox measurements of soils. In: Sparks DL (ed) Methods of soil analysis. Part 3. Chemical analysis. Soil Society of America Inc, Madison, WI, p 1255-1274

Perstorp (1992) Nitrate/nitrite flow solution methodology. Perstorp Analytical Inc, College Station, TX, Document No. 00630

Portnoy JW, Giblin AE (1997) Biogeochemical effects of seawater restoration to diked salt marshes. Ecol Appl 7: 1054-1063

Reay W, Gallagher D, Simmons GM Jr (1995) Sediment-water column nutrient exchanges in Southern Chesapeake Bay nearshore environments. Virginia Water Resources Research Center, Virginia Polytechnic Institute and State University, Blacksburg, VA, p 21 (Bull. No. 181)

Roden EE, Wetzel RG (1996) Organic carbon oxidation and suppression of methane production by microbial Fe(III) oxide reduction in vegetated and unvegetated freshwater wetland sediments. Limnol Oceanogr 41:1733-1748

Rysgaard S, Thastum P, Dalsgaard T, Christensen PB, Sloth NP (1999) Effects of salinity on $\mathrm{NH}_{4}{ }^{+}$adsorption capacity, nitrification, and denitrification in Danish estuarine sediments. Estuaries 22:21-30

Seitzinger SP (1988) Denitrification in freshwater and coastal marine ecosystems: ecological and geochemical significance. Limnol Oceanogr 33:702-724

Seitzinger SP (1994) Linkages between organic matter mineralization and denitrification in eight riparian wetlands. Biogeochemistry 25:19-39

Seitzinger SP, Gardner WS, Spratt AK (1991) The effect of salinity on ammonium sorption in aquatic sediments: implications for benthic nutrient recycling. Estuaries 14: $167-174$

Solórzano L (1969) Determination of ammonia in natural waters by the phenylhypochlorite method. Limnol Oceanogr 14: 799-801

Sorenson J (1987) Nitrate reduction in marine sediment: pathways and interactions with iron and sulfur cycling. Geomicrobiol J 5:401-422

Thompson SP, Paerl HW, Go MC (1995) Seasonal patterns of nitrification and denitrification in a natural and a restored salt marsh. Estuaries 18:399-408

Thybo-Christesen M, Blackburn TH (1993) Internal N-cycling, measured by ${ }^{15} \mathrm{NH}_{4}{ }^{+}$dilution in Cladophora sericea in a shallow Danish bay. Mar Ecol Prog Ser 100:283-286

Tiedje JM (1988) Ecology of denitrification and dissimilatory 
nitrate reduction to ammonium. In: Zehnder A (ed) Biology of anaerobic organisms. John Wiley \& Sons, London, p 179-224

Tobias CR (1999) Nitrate reduction at the groundwater-salt marsh interface. Doctoral dissertation. Virginia Institute of Marine Science, School of Marine Science, College of William and Mary, Gloucester Point, VA

Valiela I, Teal JM (1974) Nutrient limitation in salt marsh vegetation. In: Reimod RJ, Queen WH (eds) Ecology of halophytes. Academic Press, New York

Editorial responsibility: Otto Kinne (Editor),

Oldendorf/Luhe, Germany
Velinsky DJ, Pennock JR, Sharp JH, Cifuentes LA, Fogel ML (1989) Determination of the isotopic composition of ammonium-nitrogen at the natural abundance level from estuarine waters. Mar Chem 26:351-361

Weiss RF, Price BA (1980) The solubility of nitrous oxide in pure water and seawater. Mar Chem 8:347-359

Wessel WW, Tietema A (1992) Calculating gross N transformation rates of ${ }^{15} \mathrm{~N}$ pool dilution experiments with acid forest litter: analytical and numerical approaches. Soil Biol Biochem 24:931-942

Submitted: December 9, 1999; Accepted: July 4, 2000 Proofs received from author(s): January 9, 2001 